Abstract 159 Table 1 Main results
\begin{tabular}{|l|l|}
\hline All patients & $67(100 \%)$ \\
\hline N & $44(65.7 \%)$ \\
\hline Cancer types & $15(22.4 \%)$ \\
\hline Ovarian & $8(11.9 \%)$ \\
\hline Uterine & $18(26.9 \%)$ \\
\hline Other & $1(1.5 \%)$ \\
\hline Profiling test results & $38(56.7 \%)$ \\
\hline No alteration detected & $10(14.9 \%)$ \\
\hline Not enough specimen & $11 / 38(28.9 \%)+1 / 38(2.6 \%)$ \\
\hline Alteration detected & $5 / 38(13.2 \%)$ \\
\hline Ongoing & $21 / 38(55.3 \%)$ \\
\hline Treatments & \\
\hline Targeted therapy (off label) & $\begin{array}{l}\text { Targeted therapy in patients with BRCA } \\
\text { mutations within approved guidelines }\end{array}$ \\
\hline $\begin{array}{l}\text { No therapy for progressive disease/DOD } \\
\text { before starting }\end{array}$ & \\
\hline
\end{tabular}

Abstract 159 Table 2 Patients who actually started a FoundationONE ${ }^{\oplus} \mathrm{CDx}$ off-label guided therapy.

\begin{tabular}{|c|c|c|c|c|}
\hline Patient & Cancer type & Alteration detected & $\begin{array}{c}\text { Treatment started } \\
\text { (off-label) }\end{array}$ & Clinical outcome \\
\hline$\# 1$ & $\begin{array}{l}\text { High grade serous } \\
\text { ovarian cancer }\end{array}$ & CCND1 - E275* & Ribociclib & $\begin{array}{l}\text { Stability of disease; } \\
\text { Treatment ongoing } \\
\text { (5 months) }\end{array}$ \\
\hline$\# 2$ & $\begin{array}{c}\text { Endometrioid } \\
\text { endometrial cancer }\end{array}$ & PIK3СA E545K & $\begin{array}{l}\text { Everolimus } \\
\text { Exemestane }\end{array}$ & $\begin{array}{l}\text { Stability of disease; } \\
\text { Treatment ongoing } \\
\text { (6 months) }\end{array}$ \\
\hline$\# 3$ & $\begin{array}{l}\text { Mixed endometrial } \\
\text { cancer }\end{array}$ & KRAS - D33E & Trametinib & $\begin{array}{c}1 \text { month treatment } \\
\text { then clinical } \\
\text { progression of } \\
\text { disease }\end{array}$ \\
\hline$\# 4$ & $\begin{array}{l}\text { Endometrioid } \\
\text { ovarian cancer }\end{array}$ & PIK3CA - H1047L & $\begin{array}{l}\text { Everolimus- } \\
\text { Exemestane }\end{array}$ & $\begin{array}{l}\text { Stability of disease; } \\
\text { Treatment ongoing } \\
\text { (5 months) }\end{array}$ \\
\hline \#5 & $\begin{array}{c}\text { Endometrioid } \\
\text { endometrial cancer }\end{array}$ & $\begin{array}{l}\text { CCND1- } \\
\text { amplification- } \\
\text { equivocal }\end{array}$ & Palbociclib & $\begin{array}{l}1 \text { month treatment } \\
\text { then clinical } \\
\text { progression of } \\
\text { disease }\end{array}$ \\
\hline$\# 6$ & $\begin{array}{l}\text { High grade serous } \\
\text { ovarian cancer }\end{array}$ & BRCA1 - A1708E & Niraparib & $\begin{array}{c}3 \text { months of stability } \\
\text { of disease }\end{array}$ \\
\hline \#7 & $\begin{array}{l}\text { High grade serous } \\
\text { ovarian cancer }\end{array}$ & $\begin{array}{l}\text { BRCA1 - } \\
\text { rearrangement } \\
\text { intron } 12\end{array}$ & Talazoparib & $\begin{array}{c}4 \text { months of stability } \\
\text { of disease }\end{array}$ \\
\hline$\# 8$ & $\begin{array}{c}\text { Cervical } \\
\text { adenocarcinoma }\end{array}$ & $\begin{array}{c}\text { ERBB2- } \\
\text { amplification }\end{array}$ & Trastuzumab & $\begin{array}{c}4 \text { months of stability } \\
\text { of disease }\end{array}$ \\
\hline$\# 9$ & $\begin{array}{l}\text { High grade serous } \\
\text { ovarian cancer }\end{array}$ & $\begin{array}{l}\text { KRAS- Q22K } \\
\text { NF1- W2317 }\end{array}$ & Trametinib & $\begin{array}{c}9 \text { months of stability } \\
\text { of disease }\end{array}$ \\
\hline$\# 10$ & $\begin{array}{c}\text { Endometrioid } \\
\text { endometrial cancer }\end{array}$ & PIK3CA - E545K & Everolimus & $\begin{array}{l}\text { Stability of disease; } \\
\text { treatment ongoing } \\
\text { (>12 months) }\end{array}$ \\
\hline$\# 11$ & $\begin{array}{l}\text { High grade serous } \\
\text { ovarian cancer }\end{array}$ & $\begin{array}{c}\text { BRCA1 - splice site } \\
787+1 G>T\end{array}$ & Niraparib & $\begin{array}{l}1 \text { month treatment } \\
\text { then clinical } \\
\text { progression of } \\
\text { disease }\end{array}$ \\
\hline
\end{tabular}

timing of the molecular test-guided therapies. Nevertheless, with the increasing use of target-based therapy, accessibility should be granted for all patients.
IGCS20_1146

\section{THE IMPACT OF HYSTEROSCOPY ON THE DISEASE COURSE OF HIGH GRADE ENDOMETRIAL CARCINOMA}

A Larish*, A Weaver, A Mariani. Mayo Clinic, USA

\subsection{6/ijgc-2020-IGCS.139}

Background With hysteroscopy, concerns have surfaced regarding intraperitoneal spread of endometrial cancer (EC); no studies have evaluated the effect of hysteroscopy on the disease course of a large series of patients with exclusively high risk histology.

Methods Patients who underwent hysterectomy for grade 3 EC at Mayo Clinic in Rochester, MN between January 2009June 2016 were included, noting hysteroscopy within 6 months. Follow-up was restricted to five years. Cox proportional hazards models were fit to evaluate associations between hysteroscopy exposure and progression.

Results Among 831 patients, 133 underwent hysteroscopy. Patients with versus without hysteroscopy did not differ in mean age (67.7 vs. 67.8 years), BMI (31.6 vs. $31.3 \mathrm{~kg} / \mathrm{m} 2$ ), ASA $\geq 3$ (35.3\% vs. $38.3 \%)$, or serous histology (47.4\% vs. 48.7\%). Advanced disease (III/IV) was less common among hysteroscopy patients $(30.1 \%$ vs $43.8 \%, \mathrm{p}=0.003)$. No difference was observed between those with hysteroscopy versus without (all p $>0.05)$ in positive cytology $(22.0 \%$ [26/118] vs. $29.7 \%$ [191/643]), stage IV disease (16.5\% [22/133] vs. $21.9 \%$ [153/698]), any positive cytology OR adnexal invasion OR stage IV $(28.6 \%[38 / 133]$ vs. $36.1 \%$ [252/698]), the aforementioned OR peritoneal recurrence within 2 years (30.8\% [41/133] vs. 39.3\% [274/698]). After stratifying by stage, hysteroscopy did not increase risk of progression (HR 1.06 , 95\% CI $0.59-1.92$ for stage I/II; HR 0.96, 95\% CI $0.62-1.48$ for stage III/IV).

Conclusion In this retrospective study of high grade EC, we did not observe any significant association between pre-operative hysteroscopy EC and incidence of positive cytology, peritoneal disease, or progression.

\section{IGCS20 1147}

\section{PREDICTION OF OVARIAN CANCER USING A MULTIVARIATE ASSAY: A RANDOMIZED CONTROLLED TRIAL TO IMPROVE DIAGNOSTIC STRATEGIES IN FILIPINO WOMEN (PRELIMINARY RESULTS OF THE OVERA STUDY)}

${ }^{1} \mathrm{C}$ Velayo, ${ }^{2} \mathrm{~K}$ Reforma, ${ }^{2} \mathrm{R}$ Sicam*, ${ }^{1} \mathrm{M}$ Hernandez-Diwa, ${ }^{1} \mathrm{~A}$ Sy. ${ }^{1}$ University of the Philippines, Philippines; ${ }^{2}$ Philippine General Hospital, Philippines

\subsection{6/ijgc-2020-IGCS.140}

Introduction In our setting, conventional utilization of clinicodiagnostic, sonographic and single biochemical marker characteristics predominates the pre-operative evaluation of ovarian masses, while the value of multivariate assays has yet to be elucidated. In this study, a multivariate assay (OVERA ${ }^{\circledR}$ ) was compared to singular and combined models for malignancy risk calculation.

Methods This is an ongoing randomized controlled trial using OVERA among Filipino women with ovarian masses in the 